ТЕОРЕТИЧНІ ПІДХОДИ ДО ВИВЧЕННЯ ГРОМАДЯНСЬКОЇ ІДЕНТИЧНОСТІ

\title{
THEORETICAL APPROACHES TO THE STUDY OF CIVIC IDENTITY
}

Поняття «громадянська ідентичність» відносно недавно увійшло у сучасний лексикон. Широко заговорили про поняття у зв'язку з обговоренням та прийняттям освітніх державних стандартів, одним із головних завдань закладів освіти є фрормування основ громадянської ідентичності здобувачів освіти. Для вдалого фрормування громадянської ідентичності потрібно розуміти, що стоїть за цим поняттям.

Правильне розуміння сучасного стану тієі чи іншої проблеми, визначення шляхів його розвитку передбачають перш за все дослідження історії виникнення, становлення поглядів та концепцій у цій царині. Іәентичність - че френомен, дуже складний для вивчення. Однією з причин, що ускладнюють вивчення цього явища, є термінологічна плутанина. До XX cm. проблемою ідентичності не дуже переймалися, зацікавленість цим френоменом починається у 1950-х роках, коли з'являються такі терміни, як «образ Я», «самість», «Я-концепція». В деяких роботах ідентичність виступає однією з властивостей Я-концепції, а в інших вона е усвідомлюваною частиною ідентичності [9]. Загалом ідентичність (від англ. "identity" «тотожність») - це багатозначний життє вийта загальнонауковий термін, що виражає ідею постійності, тотожності, спадкоємності індивіда та його самосвідомості [6]. В академічному тлумачному словнику української мови ідентичність трактується як тотожний, однаковий [10]. Тлумачення ідентичності як тотожності, як «цілковитої схожості чого-небудь, подібності один до одного за своєю суттю й зовнішніми ознаками та виявом» подають інші сучасні словники [11]. Дослідники, як правило, аналізують конкретні різновиди ідентичності та їх особливості, а також чинники, що впливають на його фрормування. Однак ідентичність - це феномен досить складний. Існує декілька причин, які уповільнюють процес його дослідження. Одна з них пов'язана з термінологічною плутаниною у визначенні того, чим $\epsilon$ ідентичність, причому в межах навіть однієі галузі знань [8].

у запропонованій статmі проаналізовано основні напрями дослідження ідентичності та громадської ідентичності в міждисциплінарних підходах, а саме фрілософрії, соціологіі та психології. Автор акцентує увагу на взаємозв'язку ідентичності з такими поняттями, як «самовизначення», «Я-концепція», «самоцінність» та «самоусвідомлення».
Ключові слова: ідентичність, громадянська ідентичність, фрормування, розвиток, громадянськість.

The concept of "civic identity" has relatively recently entered the modern lexicon. The concepts in connection with the discussion and adoption of state educational standards have been widely discussed, and one of the main tasks for educational institutions is to form the foundations of civic identity of students. For the successful formation of civic identity, you need to understand the concept behind it.

Proper understanding of the current state of a problem, determining the ways of its development involves, above all, the study of the history of origin, the formation of views and concepts in this realm. Identity is a phenomenon that is very difficult to study. One of the reasons that complicate the study of this phenomenon is the terminological confusion. Up to the 20th century the problem of identity is not very concerned, interest in this phenomenon begins in the 1950s, there are such terms as: 'self-image", "self", "self-concept". In some works, identity is one of the properties of the "I-concept", and in others it is a conscious part of identity [9].

In the general sense, identity (from the English) is a multifaceted life and general scientific term that expresses the idea of permanence, identity, continuity of the individual and his self-consciousness [6].

In the academic explanatory dictionary of the Ukrainian language, identity is interpreted as identical, the same [10]. Interpretation of identity as identity, as "complete similarity of something, similarity to each other in nature and appearance and manifestation" is given by other modern dictionaries [11].

Researchers usually analyze specific types of identity and their features, as well as factors influencing its formation. But identity is a rather complex phenomenon. There are several reasons that slow down the process of his research.

One of them is related to terminological confusion in the definition of what is identity, and even within one area of knowledge [8]

The proposed article analyzes the main directions of the study of identity and social identity in interdisciplinary approaches - philosophy, sociology and psychology. The author focuses on the relationship of identity with concepts such as self-determination, self-concept, self-worth and self-awareness.

Key words: identity, civic identity, formation, development, citizenship.
Постановка проблеми. Проблема громадянської ідентичності порівняно недавно постала у вітчизняній науці. Феномен ідентичності розуміють як вибір у процесі становлення своєї особистої приналежності до тієї чи іншої групи або іншої людської спільності.

Громадянська ідентичність $€$ однією зі складових частин соціальної ідентичності. Разом із громадянською ідентичністю в процесі становлення особистості формуються етнічна ідентичність, вікова ідентичність, релігійна ідентичність, професійна ідентичність тощо.

Громадянська ідентичність виступає як усвідомлення приналежності індивіда до спільноти громадян тієї чи іншої держави, що є значимим для нього, а також заснована на ознаці 
громадянської спільності, що характеризує її як колективного суб'єкта.

Аналіз останніх досліджень і публікацій. Дослідженням громадянської ідентичності у своїх роботах займалися зарубіжні та вітчизняні науковці, такі як О. Данелюк, О. Кондратов, В. Тішков, Ф. Серрічіо, Ю. Габермас, Д. Хітер, Т. Бевз, Ю. Гін, О. Зорич, Л. Дробіжева, М. Кармазіна, А. Колодій, А. Секік.

Аналіз наукової літератури вказує на те, що у науковців немає єдиної точки зору щодо розуміння громадянської ідентичності. Залежно від того, яка проблема громадянської ідентичності входить до наукових інтересів дослідників, як визначальні вибираються різні аспекти її визначення.

Постановка завдання. Для успішного формування та розвитку громадянської ідентичності потрібно розуміти, що стоїть за цим поняттям, тому у викладеному матеріали нашим завданням є розгляд різноманітних теоретичних підходів до вивчення цього феномена.

Виклад основного матеріалу дослідження. Поняття «ідентичність» у психології розглядається в напрямі розвитку особистості. Ідентичність - це властивість психіки особистості в концентрованому вигляді виражати для неї те, як вона уявляє собі свою приналежність до тієї чи іншої групи або спільності. Кожний індивід одночасно шукає себе в різних напрямах, зокрема гендерному, релігійному, політичному, професійному, національному. Самоідентифікація відбувається через самопізнання та порівняння з тією чи іншою людиною як втілення притаманних певній групі або спільності властивостей.

На рівні самоаналізу та самопізнання ідентичність визначається як уявлення про себе (фізичний вигляд, темперамент, задатки), що має належне йому минуле та спрямоване в майбутнє. На рівні співвідношення себе з представниками навколишнього соціального середовища відбувається соціалізація особистості; це може бути формування професійної, національної, етнічної, релігійної ідентичності особистості.

До функцій ідентичності належать самореалізація та самоактуалізація особистості в соціально значущих видах діяльності; захисна функція, яка пов'язана з реалізацією потреб приналежності до певної групи.

Структура соціальної ідентичності незалежно від приналежності включає такі компоненти: когнітивний (знання щодо приналежності до цієї соціальної спільності); ціннісно-смисловий (позитивне, негативне чи байдуже ставлення); емоційний (реалізація своїх уявлень до приналежності); діяльнісний (реалізація своїх уявлень про приналежність до цієї спільноти в соціально значущих діях).
Досягнення самоідентичності відбувається впродовж життя людини. Протягом життя особистість крокує від однієї стадії психосоціального розвитку до іншої, і в цей час відбувається контакт із різними особистостями та формується почуття приналежності до різних груп.

Яскравим представником психоаналітичного напряму був американський психолог Е. Еріксон, з ім'ям якого традиційно пов'язують появу терміна «ідентичність» у психології. Науковець застосував поняття ідентичності для вивчення й пояснення багатьох соціальних явищ, дослідження психологічних передумов культурно-історичних змін. Він розуміє ідентичність як інтеграцію всіх попередніх ідентифікацій і Я-образів та описує два взаємозалежні поняття, такі як групова ідентичність і его-ідентичність. Групова ідентичність формується з першого дня життя людини. Его-ідентичність формується паралельно з груповою ідентичністю й створює у людини відчуття стійкості та безперервності свого «я», незважаючи на ті зміни, які відбуваються з людиною в процесі її зростання [13].

На думку Е. Еріксона, ідентичність - це індивідуальність як усвідомлене відчуття власної унікальності й власного окремого існування; тотожність і цілісність як відчуття внутрішньої тотожності, безперервності; відчуття того, що життя має узгодженість і сенс; єдність і синтез як відчуття внутрішньої гармонії та єдності, синтез образів себе й дитячих ідентифікацій в осмислене цілого, яке породжує відчуття гармонії; соціальна солідарність як відчуття внутрішньої солідарності з ідеалами суспільства й підгрупи в ньому, відчуття того, що власна ідентичність має сенс для референтної групи, а також вона відповідає їхнім очікуванням [13]. У своїх роботах учений трактує ідентичність як внутрішню безперервність і тотожність особистості, що має форму динамічного процесу, який триває протягом усього життя людини [13]. Він стверджує, що почуття ідентичності дає змогу бачити своє життя в контексті безперервності (як ретроспективно, так і перспективно) [13]. Проблему ідентичності розуміють як вибір під час установлення своєї приналежності до групи чи людської спільності. Людина ототожнює себе у зв' язку з іншою особистістю, яка є адекватним представником значимої для неї групи, тому одним із головних завдань під час дослідження ідентичності $€$ значимість та встановлення ролі значимого в процесі навчання своєї ідентичності.

Для вітчизняних дослідників проблема національної ідентичності в контексті глобалізаційних процесів $є$ відносно новою. У зв'язку з цим звернемо увагу на таку особливість сучасних теоретичних і дослідницьких напрацювань вітчизняних науковців порівняно із 
зарубіжними: якщо для західних дослідників концентрація їх наукового інтересу навколо національного та етнополітичного різновидів ідентичності зумовлена передусім глобалізацією з її руйнівними наслідками для національних держав та етнічних культур, то в Україні - триваючими процесами націєта державотворення [4].

Найбільш плідними західними науковцями, які досліджували проблему національної та громадянської ідентичності, є Б. Андерсон, А. Аппадураї, 3. Бауман, У. Бек, П. Бергер, Г. Блумер, Ф. Бродель, Р. Брюбейкер, П. Бурдьє, Б. Вальденфельс, А. Віліс, А. Вільсон, Ю. Габермас, С. Гантінгтон, Е. Гелнер, Е. Гідденс, І. Гофман, М. Грох, Р. Дарендорф, М. Еліаде, Е. Еріксон, А. Етціоні, Р. Інглегарт, М. Кастельс, Р. Кайуа, П. Козловські, С. Леш, Х. Лінц, Г. Люббе, О. Марквард, Т. Мітчелл, К. Омає, П. Рікер, А. Сен, Е. Сміт, Ч. Тейлор, Е. Тоффлер, А. Турен, Е. Хобсбаум, В. Хесле, К. Хюбнер. Феномен національної ідентичності, а саме виклики глобалізації, вивчали С. Шульман та інші науковці, у працях яких розглядалися різні загальнотеоретичні аспекти проблеми ідентичності. Мабуть, найбільш розроблену концепцію національної ідентичності серед сучасних західних дослідників запропонували С. Гантінгтон, Е. Гелнер, Е. Гідденс, Ю. Габермас, А. Етціоні, Е. Сміт, К. Хюбнер [4].

Українськими науковцями громадянська ідентичність лише недавно почала обговорюватися на концептуальному рівні у працях В. Андрущенка, Л. Губерського, В. Воронкової, Т. Воропай, П. Гнатенка, О. Зернецької, В. Кременя, І. Кресіна, В. Крисаченка, С. Куцепал, В. Лизанчука, В. Ляха, М. Михальченка, Л. Нагорної, А. Неприцького, В. Павленка, Н. Рогозина, М. Степика, Ю. Шинкаренка, Н. Черниш, Г. Яворської, а також у дисертаційних дослідженнях С. Веселовського, І. Вільчинської, Б. Глотова, Г. Лозко, М. Обушного, В. Піскун, що присвячені проблемам етнічної та національної ідентичності в сучасному українському суспільстві, культурно-цивілізаційній ідентифікації українського народу. Різні аспекти зазначеної проблеми знайшли своє відображення у працях таких вітчизняних дослідників, як Є. Андрос, А. Астаф'єв, Ю. Бадзьо, І. Бойченко, С. Веселовський, А. Гальчинський, В. Гусаченко, М. Головатий, Є. Головаха, В. Горський, О. Гриценко, І. Дзюба, М. Жулинський, О. Забужко, Г. Касьянов, А. Колодій, П. Кралюк, С. Кримський, С. Куцепал, В. Лісовий, Д. Муза, М. Обушний, Ю. Пахомов, І. Предборська, І. Прибиткова, М. Попович, О. Проценко, О. Резнік, Ю. Римаренко, М. Розумний, Т. Рудницька, А. Ручка, М. Рябчук, П. Саух, А. Свідзинський, В. Степаненко, В. Табачковський, Б. Черкес, О. Шмор- гун, С. Шостак, М. Шульга, Г. Щокін, М. Юрій, Т. Ящук. В історичному контексті проблема національної ідентичності тематизувалася такими дослідниками, як Я. Грицак, В. Литвин, М. Рябчук, Р. Кісь, З. Когут, Т. Кузьо, Д. Табачник, О. Субтельний, М. Шлемкевич, Р. Шпорлюк. Різні рівні та виміри дискурсу української ідентичності розглядалися зарубіжними дослідниками, зокрема Б. Гаврилишиним, О. Гнатюк, О. Мотилем, О. Пахльовською, І. Пріцелем, І. Рудницьким [4].

Громадянська ідентичність - це ототожнення себе зі спільнотою громадян національно-державного утворення; феномен свідомого та активного громадянства, усвідомлення себе членом громадянського суспільства. Ці два визначення громадянської ідентичності акцентують увагу на різних аспектах взаємовідносин індивіда з державою та суспільством [7].

На думку Г. Кіслої, громадянська (державна) ідентичність - це ототожнення людиною статусу громадянина як свого особистого статусу: «я є громадянин держави» [3]. Відомий етносоціолог Л. Дробіжева зазначила, що «громадянська ідентичність - «барометр» консолідації суспільства, солідарності громадських сил, певна умова цілісності держави» [2]. Однак у 20-30-х роках XX ст. Ч. Мірріамом було вжито термін «громадянська культура» для характеристики психологічних та соціологічних аспектів політичної поведінки особистості. Саме тому громадянська ідентичність вивчалась як проблема формування громадянської культури (А. Пжеворський, Ф. Лімонжі, А. Стефан, Г. Альмонд, С. Верба, Е. Тейлор) [5].

Деякі науковці пострадянського простору громадянську ідентичність визначають так: Т. Водолажська визначає громадянську ідентичність як реалізацію базових потреб особистості в приналежності до групи [1]; І. Конода наголошує на тому, що громадянська ідентичність оцінюється як політико-орієнтована категорія, у змісті якої виділяють політико-правову компетентність особистості, політичну активність, почуття громадянської спільності [12]; Н. Ядова вважає, що громадянська ідентичність постає як тотожність особистості статусу громадянина, як оцінка свого громадянського стану, готовність та здатність виконувати завдання, пов'язані з наявністю громадянських обов'язків, користуватись правами, брати активну участь у житті держави [14].

3 вищевикладеного випливає, що громадянську ідентичність визначають як розуміння приналежності до спільноти громадян тієї чи іншої держави, які мають для особистості значущий зміст, як феномен надособистістної свідомості, ознаку громадянської спільності, що характеризує її як колективний суб'єкт. Це акцентує увагу на різнихаспектахгромадянської ідентичності: з боку індивіда та спільності. 
На початку 90-х років відомий етнограф В. Тишков у своїх роботах обґрунтував ідею громадянської нації. Він вважав, що самосвідомість у особистості має бути одна, тоді як етнічна самоідентифікація може бути різна або зовсім ніяка.

Сучасні науковці, які вивчають феномен громадянської ідентичності, говорять про те, що належність людини до нації визначається на основі добровільного особистісного вибору та ототожнюється 3 громадянством. Людей об'єднує їх рівний політичний статус як громадян, рівний правовий статус перед законом, власне бажання брати участь у політичному житті держави тощо. Нація повинна будуватися з людей, які мають бажання жити поряд один $з$ одним на єдиній території, причому релігійні, етнокультурні, мовні особливості залишаються осторонь.

Висновки з проведеного дослідження. Громадянство як юридичне поняття означає правову приналежність людини до певної держави. Громадянин - це особа, якій належить у системі право певної держави. Громадянин наділений правами, свободами та має обов'язки. За своїм правовим положенням громадянин конкретної держави відрізняється від іноземних громадян та осіб без громадянства, які перебувають на території цієї держави. Зокрема, тільки громадянину належать політичні права й свободи, тому громадянин - це особа, яка готова розділити відповідальність за власну країну.

Уявлення про громадянство на рівні буденної свідомості особистості включають образ держави, що займає певну територію; провідний тип соціальних відносин у державі; систему цінностей, народ або народи, що населяють територію держави, зі своєю культурою, мовою і традиціями.

Громадянськість $€$ духовно-моральним поняттям. Критерій громадянськості визначається як цілісне ставлення особи до соціального та природного світу, здатність встановлювати баланс індивідуальних та громадських інтересів.

Виділяють такі основні якості складової частини громадянськості, як патріотизм, законослухняність, довіра до державної влади, відповідальність за вчинки, дисциплінованість, почуття власної гідності, повага до співгромадян, активна громадянська позиція, гармонічне поєднання патріотичних та національних почуттів. Патріотизм - це почуття прихильності громадянської спільності, визнання її значущою цінністю. Патріотична свідомість - це відображення суб'єктом значущості для своєї держави та готовності вжити необхідних заходів для захисту національних інтересів.

Формування громадянської ідентичності відбувається у тісному зв'язку з формуван- ням громадянської компетентності, тому під громадянською компетентністю розуміється сукупність здібностей, що дають змогу індивіду активно, відповідально та ефективно реалізовувати громадянські права та обов'язки. До сфер громадської компетентності входять компетентності пізнавальної діяльності; компетентності соціально-правової діяльності; соціально-економічна компетентність, яка розглядає придатність особистісних якостей до майбутньої вибраної професійної діяльності. Правова свідомість та соціальне уявлення щодо справедливості є невід'ємними частинами громадянської ідентичності.

\section{ЛITЕРАТУРА:}

1. Водолажская Т. Идентичность гражданская. Образовательная политика. 2010. № 5-6. C. $140-142$.

2. Дробижева Л. Идентичность и этнические установки русских в своей и иноэтнической среде. Сочиологические исследования. 2010. № 12. С. 49-58.

3. Кісла Г. Ідентичності українських студентів як фрактор конструювання міжетнічних відносин. Міжнародний науковий фрорум: соціологія, психологія, педагогіка, менеджмент. 2015. Вип. 19-20. С. 37-51.

4. Козловець М. Феномен національної ідентичності: виклики глобалізації : монографрія. Житомир : вид-во ЖДУ ім. І. Франка, 2009. 558 с.

5. Кравченко Т. Громадянська ідентичність як компонент полікуртурного виховання у закладах вищої освіти Великобританії. Наукові записки Національного університету Острозька академія. Серія: Культурологія. 2015. № 19. С. 58-65.

6. Кривоконь Н. Соціально-психологічні чинники професійної самоідентифрікації фрахівців системи соціального захисту населення : автореср. дис. ... канд. психол. наук : спец. 19.00.05. Київ, 2002. 20 с.

7. Нагорна Л. Ідентичність національна. Енциклопедія історії України. Т. 3.

8. Макарова О. Особливості розвитку профресійної ідентичності правоохоронців на етапі фрахової підготовки : дис. ... канд. психол. наук : спец. 19.00.06 «Юридична психологія». Харків, 2016. 216 с.

9. Макарова О. Особистісна ідентичність: теоретичні аспекти проблеми. Scientific Journal Virtus. 2018. September. № 26. P. 60-63.

10. Смагина С. Я и Другой : тренинги. Санкт-Петербург : Адаин Ло, 1999. 166 с.

11. Теории личности в западноевропейской и американской психологии : хрестоматия по психологии личности. Самара : Бахрах, 1996. 480 с.

12. Український журнал прикладної економіки. 2018. T. 3. № 3. 278 c.

13. Яблонська Т. Ідентичність як предмет психологічного. Наукові записки Інституту психології ім. Г. Костюка НАПН України. 2010. Вип. 38. С. 378-387.

14. Ядова Е. Особенности и практическая значимость характеристик идентичности современной молодежи в процессе социализации. Актуальные проблемы психологии труда и развития. Вестник Балтийской педагогической Академии. 2003. Вып. 50. 